\title{
PENINGKATAN EKONOMI RAKYAT BERBASIS DESA WISATA
}

\author{
Mayarni dan Geovani Meiwanda \\ FISIP Universitas Riau, Kampus Bina Widya Km. 12,5 Simpang Baru Panam, Pekanbaru 28293
}

\begin{abstract}
Improving the Tourism Village-Based People's Economy. The dynamic growth of tourist objects is a challenge for the government. Self-management by the community in the Tourism Village means providing the widest possible opportunity for the community to develop and improve the economy of the local community as a whole. Pulau Gadang Village has great potential with the emergence of various tourist attractions. The method used uses a qualitative approach. This study found that in producing tourist village formats in Pulau Gadang village in addition to requiring high aspects of community participation, this was also evidenced by legality and security aspects that must be met.
\end{abstract}

\begin{abstract}
Abstrak: Peningkatan Ekonomi Rakyat Berbasis Desa Wisata. Dinamisnya pertumbuhan objek wisata merupakan sebuah tantangan bagi pemerintah. Pengelolaan sendiri oleh masyarakat dalam Desa Wisata berarti memberikan kesempatan seluas-luas nya untuk masyarakat mampu mengembangkan dan meningkatkan ekonomi dari masyarakat lokal secara keseluruhan. Desa Pulau Gadang memiliki potensi yang besar dengan munculnya beragam objek wisata. Metode yang digunakan menggunakan pendekatan kualitatif. Penelitian ini menemukan dalam menghasilkan format desa wisata pada desa Pulau Gadang selain membutukan aspek partisipasi masyarakatnya yang tinggi, hal ini juga dibuktikan dengan aspek legalitas dan keamanan yang harus terpenuhi.
\end{abstract}

Kata Kunci: desa wisata, partisipasi masyarakat, masyarakat lokal

\section{PENDAHULUAN}

Kesiapan destinasi wisata dan kesiapan masyarakat lokal menjadi sorotan utama dalam konteks pengembangan wisata. Pemerintah sebagai penyempurna dalam melahirkan kebijakan dituntut untuk sensitif dalam melakukan upaya pengembangan. Pemerintah sebagai penggerak utama, yaitu sebagai katalisator, advokator, regulator, koordinator, fasilitator, hub agency, public outreach, dan sekaligus sebagai konsumen, yang akan senantiasa menjaga keseimbangan aspek ekonomi, sosial dan budaya, serta lingkungan. Pariwisata

Pariwisata berbasis masyarakat merupakan level terdekat dalam mengupayakan pengembangan dari sektor pariwisata, hal ini dikarenakan pada akhirnya peningkatan ekonomi masyarakat pun akan menjadi lebih baik karena masyarakat lokal sendiri yang mengembangkan dan juga mengelola pariwisata daerah nya. Partisipasi masyarakat merupakan prasyarat dalam pelaksanaan pembangunan. Pembangunan yang tidak melibatkan masyarakat akan cenderung memarginalkan masyarakat itu sendiri. Namun pada kenyataannya sering terjadi pengabaian partisipasi masyarakat, sehingga masyarakat masih menjadi objek dari pelaksanaan pembangunan.

Ulu Kasok yang menjadi objek wisata yang menjadi tajuk utama di Desa Pulau Gadang, dengan lebel yang diberikan oleh masyarakat dan wisatawan lokal sebagai Raja Ampat versi Provinsi Riau dan juga Puncak Mahligai Indah yang tidak jauh dari Objek Wisata Ulu Kasok. Kemasan merupakan hal yang menjadi sangat penting sebagai media promosi, objek wisata yang mengedepankan alam sebagai bentuk tidak lengkap jika hanya disajikan dengan pemandangan, dan pedagang kecil untuk menjajakan dagangan kecilnya, diperlukan polesan yang sangat apik tentu pariwisata berbasis masyarakat tadi lah yang menjadi kebutuhan untuk menyempurnakan objek wisata di Desa Pulau Gadang tersebut.

Pearce (1995) mengartikan pengembangan desa wisata sebagai suatu proses yang menekankan cara untuk mengembangkan atau memajukan desa wisata. Secara lebih spesifik, 
pengembangan desa wisata diartikan sebagai usaha-usaha untuk melengkapi dan meningkatkan fasilitas wisata untuk memenuhi kebutuhan wisatawan. Masyarakat lokal berperan sebagai tuan rumah dan menjadi pelaku penting dalam pengembangan desa wisata dalam keseluruhan tahapan mulai tahap perencanaan, pengawasan, dan implementasi.

Dinamisnya pertumbuhan objek wisata merupakan sebuah tantangan bagi pemerintah untuk mampu sesegera mungkin memberikan pelayanan pariwisata yang berbeda dan lebih baik bagi wisatawan, sehingga objek wisata tersebut dan upaya peningkatan ekonomi masyarakat dapat berjalan secara berkelanjutan. Pengelolaan sendiri oleh masyarakat dalam Desa Wisata berarti memberikan kesempatan seluas-luasnya untuk masyarakat mampu mengembangkan dan meningkatkan ekonomi dari masyarakat lokal secara keseluruhan.

Partisipasi memiliki pengertian yang cukup luas. Menurut Suharto dan Iryanto (1989), pengertian partisipasi adalah hal turut berperan serta di suatu kegiatan; keikutsertaan; peran serta. Maka dapat dikatakan pasrtisipasi tersebut sama dengan peran serta. Masyarakat lokal memiliki peran kontrol yang sangat substansial dalam pengembangan desa wisata karena kontrol terhadap proses pengambilan keputusan harus diberikan kepada mereka yang nantinya menanggung akibat pelaksanaan pengembangan termasuk kegagalan atau dampak negatif yang terjadi akibat pengembangan desa wisata. Keterlibatan masyarakat lokal dalam melakukan pengawasan terhadap pengembangan desa wisata terlihat minim. Alasannya, karena perencanaan pengembangan dilakukan oleh pemeritah tanpa melibatkan masyraakat, sehingga masyarakat tidak berkompetensi untuk melakukan pengawasan, dan merasat tidak perlu untuk melakukan pengawasan terhadap apa yang terjadi di sekitar mereka.

\section{METODE}

Penelitian ini merupakan penelitian melalui pendekatan kualitatif deskriptif. Peneliti melakukan diskusi dan wawancara mendalam serta forum group discusion (FGD) dengan masyarakat sekitar Desa Pulau Gadang Kabupaten Kampar. Desa wisata berarti akan berhubungan dengan keseharian masyrakat dan bagaimana partisipasi dapat muncul dari masyarakat lokal, untuk mampu mengelola desa wisata. Hal tersebut dilakukan guna mendapatkan data skunder dan terutama data primer untuk menjawab dan membantu peneliti melakukan analisis. Cresswell (2014) menjelaskan pendekatan kualitatif adalah suatu penelitian yang senantiasa meneliti pengetahuan terutama didasarkan pada perspektif konstruktif (yakni, beberapa makna eksperimen individu, makna sosial dan historis dibangun, dengan maksud untuk mengembangkan teori atau pola) atau advokasi atau perspektif partisipatif (yaitu, politik, isu berorientasi, kolaboratif, atau mengubah berorientasi) atau keduanya .

\section{HASIL DAN PEMBAHASAN}

Pengembangan kawasan yang diarahkan sebagai kawasan wisata harus memperhatikan kondisi lingkungan sekitarnya, juga aspek kelayakan dari sisi keamanan. Hal ini bertujuan agar dapat meminimalisir dampak negatif dari pengembangan desa wisata kedepannya. PLTA Koto Panjang, dalam setahun terakhir ini masyarakat sekitar Riau cukup melirik wilayah di Desa Pulau Gadang tepatnya berada di Waduk PLTA Koto Panjang. "Raja Ampat nya Riau” merupakan headline yang viral saat ini dan yang menjadi potensi besar yang dimiliki Desa Pulau Gadang, Kecamatan XIII Koto Kampar, Kabupaten Kampar. Masyarakat Desa Pulau Gadang sendiri yang memiliki dan mengelola kawasan wisata tersebut, tentu dengan kemasan sederhana namun cukup kreatif. Kelompok Sadar Wisata (Pokdarwis) merupakan organisasi masyarakat yang peduli wisata di kawasan PLTA Koto Panjang. Kelompok ini terhitung baru didirikan pada tahun 2011. Kelompok Sadar Wisata (Pokdarwis) berada dibawah pengawasan langsung Dinas Kebudayaan dan Pariwisata Kabupaten Kampar.

Potensi yang dapat dikembangkan dari Desa Pulau Gadang dapat berupa wisata minat khusus, darat maupun air, namun perlu dikemas dengan lebih menarik sehingga tidak menjadi 
objek wisata yang bersifat musiman. Potensi tersebut tentu akan mencapai dua sasaran besar, yakni pembangunan yang akan sampai pada Desa Pulau Gadang, kemudian ekonomi masyarakat pun akan berputar. Masyarakat lah yang memiliki potensi besar untuk dapat mengelola secara langsung potensi ini. Saat ini masyarakat juga sudah terlibat ditambah dengan sudah adanya Kelompok Sadar Wisata (Pokdarwisa), namun tentunya hal tersebut belum sempurna dan jika kurang diperhatikan kekhawatiran yang terjadi adalah Raja Ampat Riau tersebut hanya mampu bertahan tidak dalam jangka waktu panjang, atau hanya menjadi objek wisata musiman.

Kecendrungan yang terjadi dengan potensi yang sangat besar dimiliki oleh Desa Pulau Gadang harus dibarangi dengan beberapa aspek yang menunjang. Tidak cukup hanya dengan potensi dasar yang dimiliki tanpa tindak lanjut, dan juga tidak cukup jika hanya bertumpu kepada Kelompok Sadar Wisata (Pokdarwis).

Jika kempat aspek tersebut dapat dikelola dengan baik maka akan meningkatkan ekonomi masyarakat sekitar dengan lebih terarah. Empat aspek tersebut akan membentuk dengan baik jika membentuk format desa wisata dengan menjajahkan paket wisata di Pulau Gadang untuk wisatawan yang datang. Diperlukan kehadiran negara atau pemerintah dalam membina dan membentuk Desa Wisata, karena desa wisata tentu berbeda dengan yang ada di Bali, yang telah lama menjadi sasaran objek wisata.

\section{Aspek-aspek Pengembangan Wisata}

Empat aspek potensi dan kendala pengembangan wisata:

\section{Aspek lingkungan}

Pengembangan dan pembangunan tidak dapat dipungkiri memposisikan aspek lingkungan, sebagai opsi terakhir dari sisi dampak. Saat ini ketika berbicara mengenai pengembanguan objek wisata ataupun membentuk desa wisata akan menghasilkan serta menumbuhkan ekonomi rakyat namun tetap memperhatikan aspek lingkungan, terlebih yang sangat menjual dari potensi alam merupakan alam itu sendiri.
Aspek lingkungan dalam pengembangan wisata, sering disebut dengan Ekowisata. Ekowisata adalah suatu model pengembangan wisata yang bertanggung jawab terhadap daerah yang masih alami yang melibatkan unsur keindahan, pendidikan, pemahaman konservasi alam, dan peningkatan pendapatan masyarakat setempat (Depdagri, 2000). Ekowisata melibatkan kegiatan perjalanan/pengalaman wisata yang relatif tidak mengganggu alam dengan tujuan spesifik untuk belajar, mengagumi dan menikmati flora dan fauna liar serta budaya lokal di suatu kawasan.

\section{b. Aspek wisata}

Desa wisata tentu menyajikan paket wisata yang bukan hanya menjual wisata Raja Ampat Riau yang dapat dinikmati oleh wisatawan, daya dukung untuk kegiatan wisata menjadi daya dukung ekologi, daya dukung sosial, dan daya dukung fisik.

1). Daya dukung ekologi adalah konsep yang berkenaan dengan tingkat maksimum penggunaan wisata, baik berupa jumlah maupun aktivitas rekreasi yang dapat diakomodasi oleh suatu luasan area sebelum terjadi penurunan kualitas ekologi yang tidak dapat pulih kembali.

2) Daya dukung fisik adalah maksimum jumlah satuan penggunaan (manusia, kendaraan dsb) yang secara fisik dapat diakomodasi pada suatu area.

3) Daya dukung sosial adalah tingkat maksimum penggunaan rekreasi berupa jumlah dan aktivitas dimana pada tingkat penggunaan yang berlebihan akan menimbulkan penurunan pengalaman wisata bagi pelaku wisata. Konsep ini berkaitan erat dengan overcrowded pengunjung terhadap kenyamanan dan apresiasi pengunjung terhadap tapak.

c. Aspek sosial budaya

Masyarakat sekitar waduk memiliki kebudayaan yang dilakukan rutin setiap tahun, yaitu Balimau Kasai. Balimau Kasai adalah upara tradisional yang dilakukan untuk menyambut bulan Ramadhan. Upara ini dilakukan sehari sebelum memasuki bulan Ramadhan. Upacara ini dilakukan sebagai ungkapan rasa 
syukur akan datangnya bulan puasa dan sebagai simbol penyucian diri sebelum memasuki bulan puasa. Balimau memiliki arti mandi dengan menggunakan air yang dicampur dengan persan jeruk. Kasai adalah wangi-wangian yang dipakai untuk keramas.

Di samping upacara adat, perilaku dan kebiasaan masyarakat berkebun dapat menjadi atraksi tersendiri dalam pengembangan kegiatan wisata di Waduk Koto Panjang. Masyarakat sekitar waduk juga memiliki kesenian musik seperti musik Calempong dan dzikir gubano yang sering digunakan dalam kegiatan adat. Desa wisata tidak hanya memfasilitasi wisatawan dengan objek wisata namun juga dengan ke khasan masyarakat Desa Pulau Gadang sendiri, beragam mulai dari sejarah Muara Takus yang ikut tenggalam didasar danau, cerita sejarah PLTA Koto Panjang, kemudian bagaimana ke khas an adat istiadat dari masyarakat kampar termasuk didalamnya makanan dan jajanan khas Kmapar yang dapat ditampilkan.

Unsur ke daerah sangat dikedepankan agar pengunjung dapat merasakan atmosmer lengkap jika berkunjung ke Raja Ampat Riau yang ada di Desa Pulau Gadang, tidak hanya sekedar berfoto dari atas spot wisata saja. Atraksi budaya yang dapat dioptimalkan bagaimana bahasa keseharian bahasa Kampar. Sosial budaya merupakan aspek yang langsung dapat dan hanya bisa disajikan oleh masyarakat sekitar.

\section{d. Aspek legal}

Aspek legal tidak kalah penting dari tiga aspek sebelumnya dalam pengembangan wisata sebeulum menjadikan format Desa Wisata, karena dahulu mungkin pulau-pulau disekitar Waduk PLTA Koto Panjang maupun tanah tinggi tempat akses wisatawan melihat keindahan Raja Ampat Riau belum menjadi sesuatu yang potensial, hal ini berbeda dengan yang terjadi saat ini. Tanah-tanah yang tadi nya hanya seperti gundukan tanah tinggi dengan pohon karet maupun hutan dibiarkan begitu saja, dengan pemilik nya. Saat ini hampir sepanjang arah pandang Raja Ampat Riau melakukan penataan dan fasilitas agar masyarakat dapat berkunjung, dan kebanyakan sudah bukan milik dari masyarakat desa itu sendiri lagi.

Dampak jika terus disewa memang memberikan keuntungan bagi masyarakat Pulau Gadang, dan tidak mungkin kedepannya akan menimbulkan konflik dikemudian hari jika memang potensi wisata ini akan berkembang. Dampak selanjutnya adalah jika lahan terus dibeli oleh Pengusaha luar daerah, tanpa ada kontrol dari masyarakat desa, maka disini masyarakat desa akan menjadi pekerja di rumahnya sendiri. Desa wisata merupakan alternatif yang dapat merubah dampak ini, namun konsistensi dan komitmen masyarakat desa sangat diperlukan, kemudian kontrol dari Pemerintah Kabupaten dan Pemerintah Provinsi Riau lewat Dinas Pariwisata Provinsi Riau siap memberikan sertifikasi bagi masyarakat.

\section{Partisipasi Masyarakat dalam Pengembangan Wisata}

Partisipasi masyarakat merupakan aspek kedua dalam langkah mewujudkan desa wisata sebelum indikator dalam desa wisata itu sendiri, karena disini masyarakat ditempatkan sebagai perencana, pelaksana dan pengawas dalam memanfaatkan potensi wisata tersebut. Partisipasi disini akan dibagi atas dua bentuk, yakni:

a. Partisipasi dalam mewujudkan desa wisata Partisipasi yang dapat diwujudkan adalah masyarakat desa bersedia untuk dilakukan pembinaan atau coaching clinic, oleh instansi atau trainer yang akhirnya memberikan masyarakat sebuah ilmu untuk menjadi pengelola wisata itu sendiri, sehingga masyarakat akan tersertifikasi sebagai agen wisata. Partisipasi juga termasuk didalamnya mengetahui potensi lokal dan mengemas potensi tersebut jika berbicara ekonomi rakyat tentu pergerakan ekonomi yang tidak hanya bertumpu dari wisatawan yang datang ke Objek Wisata, namun juga memfasilitasi dengan beragam kuliner didalamnya khas dari masyarakat Kampar, juga berupa souvenir khas yang hanya bisa didapatkan jika berkunjung Raja Ampat Riau, yang nanti nya akan datang investor yang 
bersedia bekerja sama dan program-program CSR yang pada akhirnya mampu untuk menyempurnakan Desa Wisata tersebut.

b. Partisipasi dengan prinsip SAPTAPESONA

Dalam dunia pariwisata dikenal dengan istilah sapta pesona, sapta pesona merupakan suatu unsur-unsur yang harus dapat dirasakan oleh wisatakan yang berkunjung ke sebuah objek wisata. Unsur-unsur SAPTA PESONA Pariwisata (aman, tertib, bersih, nyaman, indah, ramah dan kenangan), delapan unsur tersebut merupakan sesuatu yang harus didapatkan oleh wisatawan, khususnya dari unsur ramah dan kenangan. Masyarakat Desa Pulau Gadang harus mampu memberikan kesan ramah dan kenangan terhadap wisatawakan. Pada partisipasi inilah masyarakat meunjukan local wisdom atau kekhasan dari budaya yang dimiliki oleh masyarakat itu.

\section{Indikator Berkembangnya Desa Wisata}

Desa wisata merupakan output dari kegiatan pemberdayaan masyarakat, dengan memberikan sosialisasi kemudian berdiskusi mengenai kendala yang dihadapi oleh Masyarakat Desa dan keluhan dari apartur Desa untung mengurangi kekhawatiran jika kedepan Objek Wisata Raja Ampat hanya menjadi objek wisata musiman. Pengelolaan yang baik dan berhasil mewujukan desa wisata tentu akan memutar roda perekonomian masyarakat karena masyarakat sendiri yang menjadi penjual dan penikmat keuntungan tentu diawal tetap dilakukan pendampingan. Berikut indikator dalam membentuk Desa Wisata Pulau Gadang:

\section{a. Akomodasi}

Akomodasi yang lengkap, maka Desa Pulau Gadang dapat menciptakan branding khusus dari desa tersebut, dan semua nya akan disajikan masyarakat dengan standar yang baik dan kemasan yang baik pula. Akomodasi ini bukan seperti jajanan kaki lima dengan harga yang tidak memiliki standar. Maka akomodasi merupakan aspek yang harus dijual dalam desa wisata dengan format paket wisata.

\section{b. Atraksi}

Atraksi utama memang objek wisata yang dinikmati, namun tentu tidak cukup dengan hanya melihat Raja Ampat Riau, berfoto, kemudian pulang. Atraksi akan menambah nilai jual dari Desa Pulau Gadang. Wisatawan dapat mengelilingi pulau-pulau yang berada di Waduk PLTA Koto Panjang namun setelah sampai untuk menikmati Pulau tidak cukup rasa nya jika hanya memandangi alam dan ditemani secangkir minuman, penyajian atraksi budaya dapat menjadi hiburan dan akhirnya memberi ketertarikan kepada pengunjung.

\section{SIMPULAN}

Desa Pulau Gadang merupakan desa yang memiliki untuk menjadi Desa Wisata demi menjadikan objek wisata yang dikelola masyarakat, dapat bersifat berkelanjutan. Desa Wisata akan sangat didukung dengan kekhasan dari budaya masyarakat, yang dapat dijajahkan kepada pengunjung, namun hal ini pun harus sejalan dengan kesiapan desa tersebut. Aspek legalitas dan keamanan menjadi soratan utama dalam membangun desa wisata di Pulau Gadang, namun kenyataan tanah masyarakat pun sudah mulai diperjual belikan sehingga kemungkinan untuk dikelola oleh pihak ketiga. Aspek keamanan pun perlu ditinjau kembali, seperti mempersiapkan jalur evakuasi jika kemungkinan terburuk terjadi, hal ini mempertimbangkan geografis dari PLTA Koto Panjang. Persiapan dasarpun diperlukan tingkat partisipasi masyarakat yang tinggi dan dampingan dari pemerintah daerah sebagai pemangku kebijakan.

\section{DAFTAR RUJUKAN}

Butler, R.W. (1980). The concept of tourism area cycle of evolution : implications for the management of resources. Canadian Geographer: University of Western Ontario.

Djajadi, I. (2010). Kearifan Ilmiah \& Kearifan Lokal: Pedoman bagi perumusan kearifan lokal Kalbar. Kongres Kebudayaan Kalimantan Barat II

Erickson, V. A. (2001). A research paper submitted in partial fulfillment for the masters of science degree with a major in hospitality and tourism. the graduate 
college university of wisconsin-stout. heritage tourism : a case study of the laura ingalls wilder heritage tourism site at pepin. university of wisconsin: wisconsin.

Taramatika, Fenilia. Inkorporasi Kearifan Lokal Dalam Pengembangan Kawasan Pariwisata di Lingkungan Pantai. ITB; Bandung
Walker, L. and Diana B. (1996). The Tourism action society in the kootenays : step by step guide to heritage tourism development in the kootenay-Boundary. Kootenay. 